\title{
Soil Organic Matter and Nitrogen Content as Related to Coconut Nutrition in Guerrero, Mexico
}

\author{
Jorge H. Ramírez-Silva1 ${ }^{*}$, Matilde Cortazar-Ríos², Genovevo Ramírez-Jaramillo1, \\ Carlos M. Oropeza-Salín ${ }^{3}$, Dinosca D. Rondón-Rivera ${ }^{4}$ \\ ${ }^{1}$ Centro de Investigación Regional Sureste del Instituto Nacional de Investigaciones Forestales, Agrícolas y Pecuarias (INIFAP), \\ Mérida, México \\ ${ }^{2}$ Campo Experimental Chetumal del Instituto Nacional de Investigaciones Forestales, Agrícolas y Pecuarias (INIFAP), Chetumal, \\ México \\ ${ }^{3}$ Centro de Investigación Científica de Yucatán (CICY), Mérida, México \\ ${ }^{4}$ Investigadora Independiente, Yucatán, Mexico \\ Email: ^ramirez.jorge@inifap.gob.mx
}

How to cite this paper: Ramírez-Silva, J.H., Cortazar-Ríos, M., Ramírez-Jaramillo, G., Oropeza-Salín, C.M. and Rondón-Rivera, D.D. (2021) Soil Organic Matter and Nitrogen Content as Related to Coconut Nutrition in Guerrero, Mexico. Open Access Library Journal, 8: e7727.

https://doi.org/10.4236/oalib.1107727

Received: July 3, 2021

Accepted: August 24, 2021

Published: August 27, 2021

Copyright $\odot 2021$ by author(s) and Open Access Library Inc.

This work is licensed under the Creative Commons Attribution International License (CC BY 4.0).

http://creativecommons.org/licenses/by/4.0/

\begin{abstract}
The state of Guerrero in Mexico is the main coconut copra producer with 84,881 hectares and employing more than one million wages annually. However, the production is facing very important and continuous losses due to aging of palms and a lack of technological options to enhance productivity. Farmer's soils are linked to important problems of low fertility; and the studies to understand the relationship between soil nutrients supply and coconut nutrition are practically unknown. Considering the importance of an optimum nutritional balance for high sustainable productivity of coconut and the Organic Matter (OM) being the main source of Nitrogen $(\mathrm{N})$, as the most important essential nutrient, it was fundamental to quantify both $\mathrm{OM}$ and $\mathrm{N}$ soil ( 0 - 30 and $30-60 \mathrm{~cm}$ deep) as related to the nutritional status of the crop in fifteen plantations from Costa Chica and Costa Grande regions. Critical levels of $\mathrm{OM}(\%)$, inorganic $\mathrm{N}$ as $\mathrm{NO}_{3}^{-}$(ppm) and Total $\mathrm{N}(\%)$ in leaves, suggested by the literature, were considered as reference values. Soil properties were considerably heterogeneous among localities. Total average of soil $\mathrm{OM}(\%)$, and $\mathrm{N}^{-\mathrm{NO}_{3}^{-}}$in both Costa Chica and Costa Grande were quite low at both depths. The total average of OM in Costa Chica was almost the same at both depths with $1.37 \%$ and $1.33 \%$ respectively and as for Costa Grande the total average of OM varied from 1.29 to 0.71 , all below the reference Medium Value of $1.6 \%$ to $3.5 \%$. The same deficiencies trend was shown by the foliar $\mathrm{N}$ contents (\%) where $\mathrm{N}$ fluctuated from $1.18 \%$ to $1.77 \%$, in Costa Chica and $0.94 \%$ to $1.72 \%$ in Costa Grande. The best correlation model to better explain
\end{abstract}


the relationship between soil attributes and Foliar $\mathrm{N}$ was found when the soil $\mathrm{N}-\mathrm{NO}_{3}$, at $30-60 \mathrm{~cm}$ deep, was compared to the Foliar $\mathrm{N}$ in Costa Chica.

\section{Subject Areas}

Agricultural Engineering

\section{Keywords}

Essential Nutrients, Deficiencies, Heterogeneity, Critical Levels

\section{Introduction}

The coconut palm (Cocos nucifera L.) is cultivated in 93 countries [1] and grown widely in Asia and the Pacific region [2]. In Mexico, its cultivation started more than a century ago, but it was not until the 1940's when it began to be commercialized [3]. For several years, copra production was fundamental for the economic development of both Mexican Gulf and the Pacific coastal areas [4]. The interest in coconut was related to various government policies and the reduction in world supply.

The cultivation of coconut (Cocos nucifera L.) in Mexico comprises 190,000 hectares distributed in 13 states. The production of copra is the main product, mainly concentrated in the states of Guerrero, Colima and Tabasco. One million tons of coconut can yield around 166,000 t of copra and 100,000 t of oil mostly dedicated to the soap industry [5].

It has been reported that the state of Guerrero has 84,881 hectares of coconut plantations [6] [7] and it is being considered as the main copra producer at national level, employing more than one million wages annually and the production is mainly (80\%) oriented to copra to satisfy national factories.

However, and in spite of the increasing interest in coconut products and by-products, at international level, there are statistics that assume that Guerrero is facing a constant surface reduction to just 44,387 existing hectares according to specific surveys made to the coconut producers [8]; and that plantations are losing their potential due to aging (more than 60 years) and lack of technological options able to rescue the natural potential of soils.

In addition, farmer's lands have important problems of soil fertility; and the relationship between soil fertility and coconut nutrition is practically unknown. The few available information is most referred to tall varieties from other countries [9].

Soil and plant analysis are basic tools to evaluate the nutrient status of soils and its relationship with plant nutrition since it has been proved that plant nutrient deficiencies can reduce the number of female flowers per spathe and fruits, causing the "abortion of immature fruits" [10] [11].

Nitrogen is the first required essential nutrient for young coconut palms fol- 
lowed by phosphorus (P) and potassium (K). Supplementation with $\mathrm{N}$ is the most required by the coconut tree [12]. According to Sobral (1998) [13] the lack of $\mathrm{N}$ causes a yellowing of older leaves and there is a reduction in the number of female flowers. On the other hand, the nutritional balance is essential to have a high sustainable productivity [14].

This work was conducted to evaluate the status of both Organic Matter and Nitrogen $\left(\mathrm{N}^{-} \mathrm{NO}_{3}\right)$ in soils of different coconut farms of Guerrero Mexico, and their relationship with the levels of Nitrogen in the palms.

\section{Materials and Methods}

The study was carried out in the dry season of 2019 in the state of Guerrero, Mexico located between $16^{\circ} 42^{\prime} 45^{\prime \prime}$ to $17^{\circ} 05^{\prime} 51^{\prime \prime}$ North Latitude and from $99^{\circ} 13^{\prime} 08^{\prime \prime}$ to $100^{\circ} 28^{\prime} 58^{\prime \prime}$ West Longitude. The soils are classified as Regosols according to the World Reference Base for Soil Resources (WRBSR) with a texture classified as Sandy Loam, Silty Loam and Clay Loam. In Table 1, the main soil properties of the studied area are being shown [15].

Fifteen coconut plantations were selected scattered in both Costa Chica and Costa Grande regions with a warm sub-humid climate Awo [16] and an average annual rainfall of $1200 \mathrm{~mm}$. In Table 2 and Table 3 the distribution of farms, for each region, are being shown as well as their Geographical position, coconut ecotypes and number of soil and foliar samples that were taken.

Table 1. Soil properties of the studied area in Guerrero, Mexico.

\begin{tabular}{cccccc}
\hline Region & $\begin{array}{c}\text { Depth } \\
(\mathrm{cm})\end{array}$ & $\begin{array}{c}\text { Bulk density } \\
\left(\mathrm{g} / \mathrm{cm}^{3}\right)\end{array}$ & $\mathrm{pH}(1: 1)$ & $\begin{array}{c}\text { Electrical } \\
\text { Conductivity } \\
(\mathrm{mS} / \mathrm{cm})\end{array}$ & $\begin{array}{c}\text { Cation Exchange } \\
\text { Capacity } \\
(\mathrm{meq} / 100 \mathrm{~g})\end{array}$ \\
\hline Costa Chica & $0-30$ & $1.00-1.23$ & $5.5-6.2$ & $0.14-0.69$ & $13-23$ \\
& $30-60$ & $1.15-1.27$ & $5.7-6.9$ & $0.16-1.78$ & $13-19$ \\
Costa Grande & $0-30$ & $1.18-1.36$ & $5.4-7.1$ & $0.18-1.70$ & $8-21$ \\
& $30-60$ & $1.00-1.36$ & $5.7-7.4$ & $0.22-1.09$ & $4-21$
\end{tabular}

Table 2. Geographical position, coconut ecotypes and number of samples from selected farms in different municipalities of Costa Chica Guerrero, Mexico.

\begin{tabular}{ccccccc}
\hline & \multicolumn{5}{c}{ Geographical Position/Coconut Ecotype/Samples } \\
\cline { 2 - 6 } Municipality & Localities & North Latitude & West Longitude & Ecotype & $\begin{array}{c}\text { Number of individual Number of composite } \\
\text { soil samples }\end{array}$ & foliar samples \\
\hline Copala & Copala-1 & 16.62374 & 99.02175 & Hybrid & 8 & 2 \\
Copala & Copala-2 & 16.59862 & 99.00607 & Pacific Tall & 8 & 2 \\
San Marcos & Altos de Ventura & 16.71272 & 99.21680 & Green Dwarf & 10 & 2 \\
Florencio Villarreal & San José de las Flores & 16.63959 & 99.21392 & Pacific Tall & 4 & 1 \\
Marquelia & Marquelia-1 & 16.58835 & 98.81512 & Pacific Tall & 4 & 1 \\
Marquelia & Marquelia-2 & 16.54293 & 98.76108 & Pacific Tall & 2 & 1 \\
\hline
\end{tabular}


Table 3. Geographical position, coconut ecotypes and number of samples from selected farms in different municipalities of Costa Grande Guerrero, Mexico.

\begin{tabular}{|c|c|c|c|c|c|c|}
\hline \multirow[b]{2}{*}{ Municipality } & \multicolumn{6}{|c|}{ Geographical position/Coconut Ecotype/Samples } \\
\hline & Localities & Latitude North & Longitude West & Ecotype & $\begin{array}{l}\text { Number of individual } \\
\text { soil samples }\end{array}$ & $\begin{array}{l}\text { Number of composite } \\
\text { foliar samples }\end{array}$ \\
\hline Tecpan de Galeana & Aguas Blancas & 17.18375 & 100.61782 & Green Dwarf & 10 & 3 \\
\hline Tecpan de Galeana & Tenexpa & 17.18235 & 100.67571 & Green Dwarf & 4 & 1 \\
\hline Tecpan de Galeana & San Luís-San Pedro & 17.24121 & 100.87041 & Pacific Tall & 10 & 2 \\
\hline Tecpan de Galeana & Rodesia & 17.19916 & 100.71172 & Pacific Tall & 2 & 1 \\
\hline Benito Juárez & Las Tunas & 17.096790 & 100.48046 & Green Dwarf & 18 & 3 \\
\hline Atoyac de Álvarez & Alcholoa & 17.13704 & 100.38474 & Pacific Tall & 10 & 2 \\
\hline Atoyac de Álvarez & Cacalutla & 17.09784 & 100.37756 & Pacific Tall & 4 & 2 \\
\hline Atoyac de Álvarez & El Huicon & 17.11313 & 100.29875 & Pacific Tall & 4 & 1 \\
\hline Coyuca de Benítez & Coyuca & 16.99871 & 100.08382 & Pacific Tall & 2 & 1 \\
\hline
\end{tabular}

\subsection{Soil Sampling}

For those farms with five hectares or more, individual soil samples per hectare were taken whilst for those ones with less than five hectares three subsamples per hectare were mixed in order to get a composite sample. Samples were taken at one-meter distance from coconut trunk at both $0-30 \mathrm{~cm}$ and $30-\mathrm{cm}$ depth per boring. The number of samples depended on the surface (hectares) of each farm. The general criterion was to have one sample per about one hectare in homogeneous surfaces to be sent to the laboratory.

For instance, when the area to be sampled was 10 hectares, such as Las Tunas in Costa Grande, 9 borings were made considering both depths per boring. A total of 18 samples were taken ensuring to obtain enough samples for good chemical interpretation. For those farms with just 1 hectare, 3 subsamples were mixed to form a single composite sample. It is suggested that 7 to 20 subsamples per each 5 to 10 hectares are appropriate in homogeneous surfaces [17] like those ones of this study.

\subsection{Foliar Sampling}

Foliar samplings were made from full competition palms considering the leaf number 9 as suggested by Sobral (1998) [13]. One composite foliar sample per each 2 - 3 hectares was taken. In the case of 1 hectare farms, just one composite sample was considered. All composite samples were formed by mixing three subsamples, and each subsample was made of 15 pieces of coconut leaflets of 20 $\mathrm{cm}$ long taken from three palm trees (5 leaflets per tree).

The $20 \mathrm{~cm}$ pieces of leaflets were cut from the middle third of leaves number 9; and at the same time the leaflets were taken from the middle third of the entire long leaflet. 


\subsection{Soil and Foliar Analysis}

The soil samples were chemically analyzed for Nitrogen $(\mathrm{N})$ as Nitrate $\left(\mathrm{N}-\mathrm{NO}_{3}\right)$; this being the most readily form used by higher plants and by consequence it is the available $\mathrm{N}$ form that usually accumulates in agricultural lands [18].

Brucina was the method of soil analysis used for $\mathrm{N}-\mathrm{NO}_{3}$ determination which is based on the reaction of ions nitrate present in a sample with sulfate of brucine in the presence of sulfuric acid, forming a yellow complex measurable at a length wavelength of $410 \mathrm{~nm}$ in an ultraviolet visible spectrophotometer. The measure of color intensity is proportional to the concentration of nitrate ion present [19].

On the other hand, the Kjeldall method [20] was used to determine Total Nitrogen (TN) in leaves consisting of the sum of organic nitrogen in its various forms (proteins and nucleic acids in various states of degradation, urea, amines, etc.) and the ammonium ion $\mathrm{NH}_{4}^{+}$, present in the sample. The quantified $\mathrm{TN}$ was compared to the reference values reported by different authors for coconut.

\subsection{Reference Soil Values for $\mathrm{OM}$ and Inorganic $\mathrm{N}$}

For proper evaluation, critical levels of OM, in percentage (\%) and inorganic assimilable $\mathrm{N}$ such as $\mathrm{N}-\mathrm{NO}_{3}$ in parts per million (ppm), suggested by the SEMARNAT (2002) [20] were considered as a reference for the discussion (Table 4).

All samples with contents below the Medium Rate were graded as Deficient and those ones with higher values than the Medium Rate were considered to have sufficient amounts of soil $\mathrm{OM}$ and $\mathrm{N}-\mathrm{NO}_{3}$.

\subsection{Reference Foliar Values of $\mathrm{N}$ in Leaf $\mathrm{N}^{\circ} 9$ for Different Coconut Types}

In the case of foliar analysis, the critical levels for different leaves numbers (including leaf $\mathrm{N}^{\circ}$ 9) do not show big differences. The critical levels used as reference values were those ones reported in percentage (\%) by the literature [21] [22] [23] as it is shown in Table 5. The main advantage of this method is to be able to know directly how sufficient or deficient is the plant nutrient just for comparing it with the reference value (critical level).

Table 4. Reference levels of organic matter (OM) and inorganic nitrogen suggested by the SEMARNAT (2002) [20].

\begin{tabular}{ccc}
\hline \multirow{2}{*}{ Soil-test rating } & \multicolumn{2}{c}{ Soil Attributes } \\
\cline { 2 - 3 } & $\mathrm{OM}(\%)$ & $\mathrm{N}^{-\mathrm{NO}_{3}}(\mathrm{ppm})$ \\
\hline Very Low & $<0.5$ & $0-10$ \\
Low & $0.6-1.5$ & $10-20$ \\
Medium & $1.6-3.5$ & $20-40$ \\
High & $3.6-6.0$ & $40-60$ \\
Very High & $>6.0$ & $>60$ \\
\hline
\end{tabular}


Table 5. Reference levels of total N (\%) in different coconut ecotypes.

\begin{tabular}{ccc}
\hline \multirow{2}{*}{ Coconut type } & \multicolumn{2}{c}{ Leaf $\mathbf{N}^{\bullet} \mathbf{9}$} \\
\cline { 2 - 3 } & Total N (\%) & Reference \\
\hline Tall & 2.2 & Magat (1991) [21] \\
Hybrid & 2.2 & Magat (1991) [21] \\
Green Dwarf & $1.8-2.0$ & Sobral and Santos (1987) [22] Benassi et al. (2013) [23] \\
\hline
\end{tabular}

\subsection{Statistical Analysis}

All parameters were submitted to a statistical analysis considering the Coefficient of Variation (CV) and the Coefficient of Correlation $(r)$ and Determination $\left(\mathrm{R}^{2}\right)$.

The CV was considered as the standard deviation (Sd) of a sample expressed as a percentage of the arithmetic mean [24]. The largest dispersion will correspond to the value of the largest $\mathrm{CV}$. The higher the $\mathrm{CV}$ value the greater the heterogeneity of the variable; and the lower the CV the greater the homogeneity. Normally, in agricultural field trials, CV's are considered low when they are less than $10 \%$; medium from $10 \%$ to $20 \%$, high from $20 \%$ to $30 \%$ and very high above $30 \%$ [25].

CV's lower than or equal to $30 \%$ indicate that the data set is "Homogeneous" and when exceeding $30 \%$, the data set is considered "Heterogeneous". Muñoz et al. (2006) [26] have reported CV values of $20 \%$ to $40 \%$ as Medium and less than $10 \%$ as Low variability.

The $r$ measured the linear dependence between two quantitative random dependent $(y)$ and independent $(x)$ variables. It was considered as an index to measure the degree of relationship between: $\mathrm{OM}$ vs. $\mathrm{N}^{-\mathrm{NO}_{3}}, \mathrm{OM}$ vs. Foliar $\mathrm{N}$ and $\mathrm{N}-\mathrm{NO}_{3}$ vs. Foliar $\mathrm{N}$ in the two regions and soil depths studied. The expression $y=$ function $(f)$ of $(x)$ was considered as linear depending on the distribution trend of points in the graphs.

The $\mathrm{R}^{2}$ quantified the proportion (\%) of the total values of the dependent-y variable which can be explained by changes of the independent- $x$ values. It can range between 0 and $1(0 \%-100 \%)$. An $\mathrm{R}^{2}$ closer to $1(100 \%)$ can better explain the model meaning a strong linkage between variables.

\section{Results and Discussion}

\subsection{Organic Matter and $\mathrm{N}-\mathrm{NO}_{3}$ in Soils of Costa Chica}

Regarding OM (\%) in Costa Chica, it is observed (Table 6) that the total average, of all six soils, are quite low at both depths $(0-30$ and $30-60 \mathrm{~cm})$. The total average of $\mathrm{OM}$ is almost the same at both depths with $1.37 \%$ and $1.33 \%$ respectively and no one reached the reference Medium Rate Value of $1.6 \%$ to $3.5 \%$. However, considering specific sites at $0-30 \mathrm{~cm}$, Altos de Ventura, San José de la Flores and Marquelia-1 had Medium content of OM whilst Copala-1, Copala-2 and Marquelia-2 had the lowest values. 
Table 6. OM (\%) and $\mathrm{N}-\mathrm{NO}_{3}(\mathrm{ppm})$ content at $0-30$ and $30-60 \mathrm{~cm}$ in different coconut farms from Costa Chica Guerrero, Mexico.

\begin{tabular}{|c|c|c|c|c|}
\hline \multirow{2}{*}{ Localities } & \multicolumn{2}{|c|}{$0-30 \mathrm{~cm}$} & \multicolumn{2}{|c|}{$30-60 \mathrm{~cm}$} \\
\hline & $\mathrm{OM}$ & $\mathrm{N}-\mathrm{NO}_{3}$ & $\mathrm{OM}$ & $\mathrm{N}-\mathrm{NO}_{3}$ \\
\hline Copala (1) & $1.07(\mathrm{~L})$ & $3.8(\mathrm{VL})$ & $0.57(\mathrm{~L})$ & $4.0(\mathrm{VL})$ \\
\hline Copala (2) & $1.22(\mathrm{~L})$ & $4.0(\mathrm{VL})$ & $1.74(\mathrm{M})$ & $5.4(\mathrm{VL})$ \\
\hline Altos de Ventura & $2.05(\mathrm{M})$ & $6.08(\mathrm{VL})$ & $0.76(\mathrm{~L})$ & $3.8(\mathrm{VL})$ \\
\hline San José de las Flores & $2,14(\mathrm{M})$ & $5.6(\mathrm{VL})$ & $0.94(\mathrm{~L})$ & $5.2(\mathrm{VL})$ \\
\hline Marquelia (1) & $1.77(\mathrm{M})$ & $12.8(\mathrm{~L})$ & $1.27(\mathrm{~L})$ & $4.0(\mathrm{VL})$ \\
\hline Marquelia (2) & $0.74(\mathrm{~L})$ & $0.8(\mathrm{VL})$ & $1.94(\mathrm{M})$ & $6.4(\mathrm{VL})$ \\
\hline AVERAGE & $1.37(\mathrm{~L})$ & $5.51(\mathrm{VL})$ & $1.33(\mathrm{~L})$ & $4.81(\mathrm{VL})$ \\
\hline SD & 0.67 & 3.67 & 0.64 & 0.94 \\
\hline CV (\%) & 48.93 & 66.59 & 48.48 & 19.52 \\
\hline $\mathbf{R}$ & \multicolumn{2}{|c|}{0.61} & \multicolumn{2}{|c|}{0.80} \\
\hline $\mathbf{R}^{2}$ & \multicolumn{2}{|c|}{0.38} & \multicolumn{2}{|c|}{0.65} \\
\hline
\end{tabular}

Going deeper to $30-60 \mathrm{~cm}$, the amount of OM graded Low in four of the six soils: Copala-1, Altos de Ventura, San José de las Flores, Marquelia-1 and exceptionally the soils of Copala-2 and Marquelia-2 showed Medium values. The OM content in the $30-60 \mathrm{~cm}$ subsoil was expected to be lower than that of the $0-30$ $\mathrm{cm}$ topsoil in all sites; however, the exception was Copala- 2 where the OM content was higher in the subsoil with $1.74 \%$ and $1.22 \%$ in the topsoil; the same trend was found in Marquelia-2 where the OM contents were drastically different with $0.74 \%$ and $1.94 \%$ for topsoil and subsoil respectively. This unusual trend may be related to past floods caused by tropical storms, affecting the region, and buried the original OM of the topsoil. This fact was reported by Ramirez Silva et al. (2018) [27] when studying chemical soil changes in the same regions of Guerrero, Mexico.

In the case of $\mathrm{N}$ as $\mathrm{NO}_{3}$, the total average of the six soils were 5.81 and 4.81 ppm at $0-30$ and $30-60 \mathrm{~cm}$ respectively, graded as Very Low. Being specific, except for Marquelia-1, all sites graded Very Low for $\mathrm{N}$. The minimum value was for Copala-1 with $3.8 \mathrm{ppm}$ and the maximum was for Marquelia-1 with 12.8 ppm at $0-30 \mathrm{~cm}$ whilst at $30-60 \mathrm{~cm}$ the lowest value was for Altos de Ventura with $3.8 \mathrm{ppm}$ and the highest one was for Marquelia-2 with $6.4 \mathrm{ppm}$.

In some specific cases, Nitric nitrogen $\left(\mathrm{N}-\mathrm{NO}_{3}\right)$ increased with the soil depth and can be explained by a leaching process, from surface soils to the subsoils, which constantly occurs in sandy soils [28].

In regard to the CV's, as an index of heterogeneity among sites, it was found (Table 4) high variability, for all soil attributes, with CV values of $48.93 \%$ and $66.59 \%$ for $\mathrm{OM}$ and $\mathrm{N}-\mathrm{NO}_{3}$ respectively at $0-30 \mathrm{~cm}$; and $48.48 \%$ for $\mathrm{OM}$ and $19.52 \%$ for $\mathrm{N}^{-\mathrm{NO}_{3}}$ at $30-60 \mathrm{~cm}$.

The foregoing is very important in order to maintain the soil quality if when 
considering a sustainable agriculture [29]. In the case of the coconut farms of Guerrero, Mexico, the high CV's founded suggest that any technological innovation, mainly in the use of fertilizers, should be different among sites.

On the other hand, there was found, at $0-30 \mathrm{~cm}$ deep, a positive Medium Correlation index $(r)$ of 0.61 between soil OM vs. $\mathrm{N}^{-\mathrm{NO}_{3}}$ and an important high correlation of 0.80 between soil $\mathrm{OM}$ vs. $\mathrm{N}^{-\mathrm{NO}_{3}}$ at $30-60 \mathrm{~cm}$. However, the Determination Index $\left(\mathrm{R}^{2}\right)$ suggests that changes in the amount of $\mathrm{N}-\mathrm{NO}_{3}$, in the soil, depend $38 \%$ on changes in the soil OM on the surface and $65 \%$ in the subsoil as it is shown in Figure 1 and Figure 2.

\subsection{OM and N in Soils of Costa Grande}

As it is shown in Table 7, the total average of OM, in the sites of Costa Grande, showed to be in the low range with $1.29 \%$ and $0.71 \%$ for both depths $0-30$ and $30-60 \mathrm{~cm}$ respectively. However, specifically Tenexpa (1.61), Las Tunas (2.74) and El Huicon (1.65) graded as Medium content of $\mathrm{OM}$ at $0-30 \mathrm{~cm}$ depth representing one third of the total samples. However, at $30-60 \mathrm{~cm}$ the amount

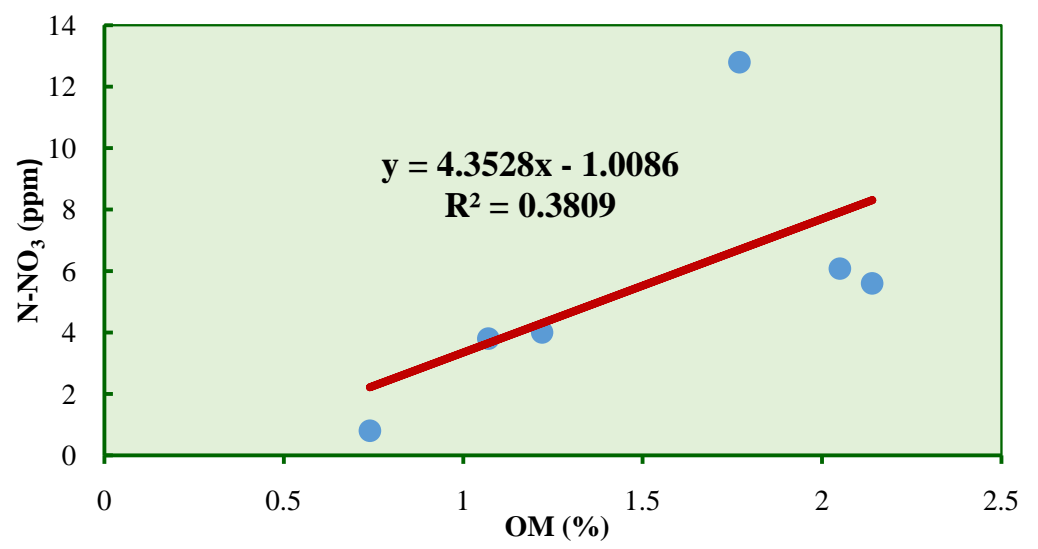

Figure 1. Correlation between organic matter and $\mathrm{N}-\mathrm{NO}_{3}$ at $0-30 \mathrm{~cm}$ deep in soils of Costa Chica Guerrero, Mexico.

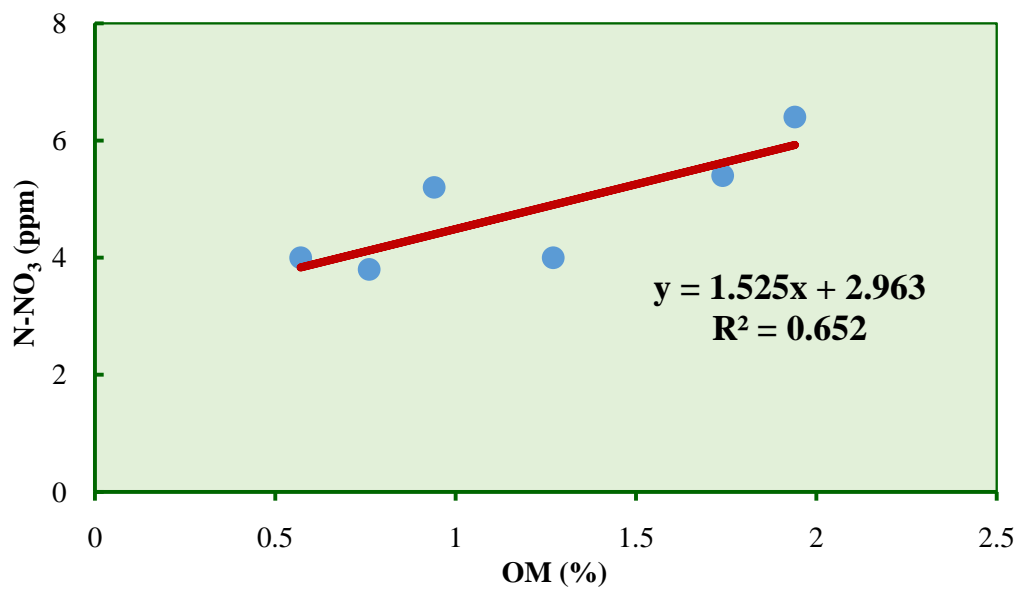

Figure 2. Correlation between organic matter and $\mathrm{N}-\mathrm{NO}_{3}$ at $30-60 \mathrm{~cm}$ deep in soils of Costa Chica Guerrero, Mexico. 
Table 7. $\mathrm{OM}(\%)$ and $\mathrm{N}-\mathrm{NO}_{3}(\mathrm{ppm})$ content at $0-30$ and $30-60 \mathrm{~cm}$ deep in different coconut farms from Costa Grande Guerrero, Mexico.

\begin{tabular}{|c|c|c|c|c|}
\hline \multirow{2}{*}{ Localities } & \multicolumn{2}{|c|}{$0-30 \mathrm{~cm}$} & \multicolumn{2}{|c|}{$30-60 \mathrm{~cm}$} \\
\hline & $\mathrm{OM}$ & $\mathrm{N}-\mathrm{NO}_{3}$ & $\mathrm{OM}$ & $\mathrm{N}-\mathrm{NO}_{3}$ \\
\hline Aguas Blancas & $0.73(\mathrm{~L})$ & $17.44(\mathrm{~L})$ & $0,22(\mathrm{VL})$ & $10.88(\mathrm{~L})$ \\
\hline Tenexpa & $1.61(\mathrm{M})$ & $9.20(\mathrm{VL})$ & $1.04(\mathrm{~L})$ & $5.20(\mathrm{VL})$ \\
\hline San Luís-San Pedro & $1.09(\mathrm{~L})$ & $9.76(\mathrm{VL})$ & $0.28(\mathrm{~L})$ & $5.92(\mathrm{VL})$ \\
\hline Rodesia & $1.54(\mathrm{~L})$ & $9.60(\mathrm{VL})$ & $0.80(\mathrm{~L})$ & $4.00(\mathrm{VL})$ \\
\hline Las Tunas & $2.74(\mathrm{M})$ & $29.64(\mathrm{M})$ & $1.49(\mathrm{~L})$ & $19.73(\mathrm{~L})$ \\
\hline Alcholoa & $0.79(\mathrm{~L})$ & $12.96(\mathrm{~L})$ & $0.29(\mathrm{VL})$ & $13.28(\mathrm{~L})$ \\
\hline Cacalutla & $0.48(\mathrm{~L})$ & $8.00(\mathrm{VL})$ & $0.27(\mathrm{VL})$ & $3.20(\mathrm{VL})$ \\
\hline El Huicon & $1.65(\mathrm{M})$ & $6.40(\mathrm{VL})$ & $0.87(\mathrm{~L})$ & $4.40(\mathrm{VL})$ \\
\hline Coyuca & $1.01(\mathrm{~L})$ & $7.36(\mathrm{VL})$ & $0.60(\mathrm{~L})$ & $3.36(\mathrm{VL})$ \\
\hline Media & 1.29 & 12.26 & 0.71 & 7.77 \\
\hline Ds & 0.64 & 6.90 & 0.44 & 5.37 \\
\hline CV (\%) & 49.81 & 56.28 & 62.71 & 69.01 \\
\hline $\mathbf{r}$ & \multicolumn{2}{|c|}{0.58} & \multicolumn{2}{|c|}{0.35} \\
\hline $\mathbf{R}^{2}$ & \multicolumn{2}{|c|}{0.34} & \multicolumn{2}{|c|}{0.12} \\
\hline
\end{tabular}

of OM ranged from Low: Tenexpa (1.04), San Luís-San Pedro (0.28), Rodesia (0.80), Las Tunas (1.49), El Huicón (0.87), Coyuca (0.60) to very low: Aguas Blancas (0.22), Alcholoa (0.29) and Cacalutla (0.27).

In Costa Grande all sites showed lower amounts of OM in the subsoil (30 - 60 $\mathrm{cm}$ deep) than those found in the topsoil (0 - $30 \mathrm{~cm}$ deep). The outstanding OM behavior was in Las Tunas due to the highest amount of OM found as compared to the other sites with $2.74 \%$ and $1.49 \%$ of OM at both depths ( $0-30$ and $30-60$ $\mathrm{cm})$ respectively.

Studies by Sales Davila 2006 [30], on Peruvian soils, have shown higher amount of OM in the topsoil $(0-20 \mathrm{~cm})$ than in the subsoil $(20-40 \mathrm{~cm})$. However, it was remarkable to find that the OM in some subsoils $(20-40 \mathrm{~cm})$ were higher than $2 \%$. This is relevant when dealing with Carbon (C) sequestration in deep horizons [31].

In the case of $\mathrm{N}^{-\mathrm{NO}_{3}}$ (ppm), six out of nine sites of Costa Grande, at 0 - 30 $\mathrm{cm}$, were graded as Very Low: Tenexpa (9.20), San Luís-San Pedro (9.76), Rodesia (9.60), Cacalutla (8.0), El Huicon (6.40), Coyuca (7.36). Aguas Blancas and Alcholoa showed a Low $\mathrm{N}-\mathrm{NO}_{3}$ content with 17.44 and 12.96 ppm whilst Las Tunas showed to be, as in the case of OM, the highest amount of $\mathrm{N}$ with 29.64 ppm although it is still in the low grade range.

In the subsoil, at $30-60 \mathrm{~cm}$, six out of nine sampled localities graded Very Low: Tenexpa (5.2), San Luís-San Pedro (5.92), Rhodesia (4.00), Cacalutla (3.20), El Huicon (4.40), Coyuca (3.36) whilst Aguas Blancas, Las Tunas and Alcholoa 
graded Low with $18.88,19.73$ and 13.28 ppm respectively.

The results found in this work agree with Malhotra et al. (2017) [32] who mentioned that in India: the sandy soils contain very low amount of soil nitrogen and leaching loss of nitrate is very high in sandy soil followed by sandy loam and red soils.

The CV (Table 7), indicates very high heterogeneity among sites regardless of the measured parameter. The CV's ranged from $49.81 \%$ for OM in the $0-30 \mathrm{~cm}$ topsoil to $69.01 \%$ for $\mathrm{N}$ in the $30-60 \mathrm{~cm}$ subsoil. The Correlation Index was found to be Medium $(r=0.58)$ and Low $(r=0.35)$ when comparing the soil OM with the $\mathrm{N}^{-\mathrm{NO}_{3}}$ at $0-30$ and $30-60 \mathrm{~cm}$ respectively. The determination coefficient $\left(\mathrm{R}^{2}\right)$ were of 0.34 and 0.12 at both depths; so the $\mathrm{N}-\mathrm{NO}_{3}$ content can only be explained just in a $34 \%$ (Figure 3 ) and $12 \%$ by changes in the OM.

\subsection{Total $\mathrm{N}$ in Leaf Number 9 of Coconut in Costa Chica and Costa Grande}

In Figure 4 and Figure 5 are being shown the Total $\mathrm{N}$ contents (\%) in leaf number 9 from six coconut farms of Costa Chica and Costa Grande. According to the critical levels $(1.8 \%-2.2 \%)$, already mentioned, all sampled coconut palms

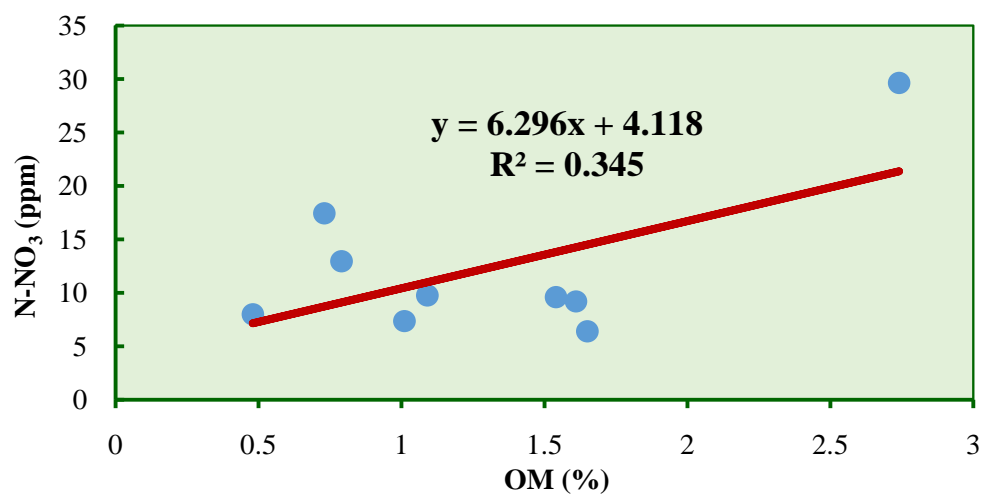

Figure 3. Correlation between organic matter and $\mathrm{N}-\mathrm{NO}_{3}$ at $0-30 \mathrm{~cm}$ in Costa Grande Guerrero Mexico.

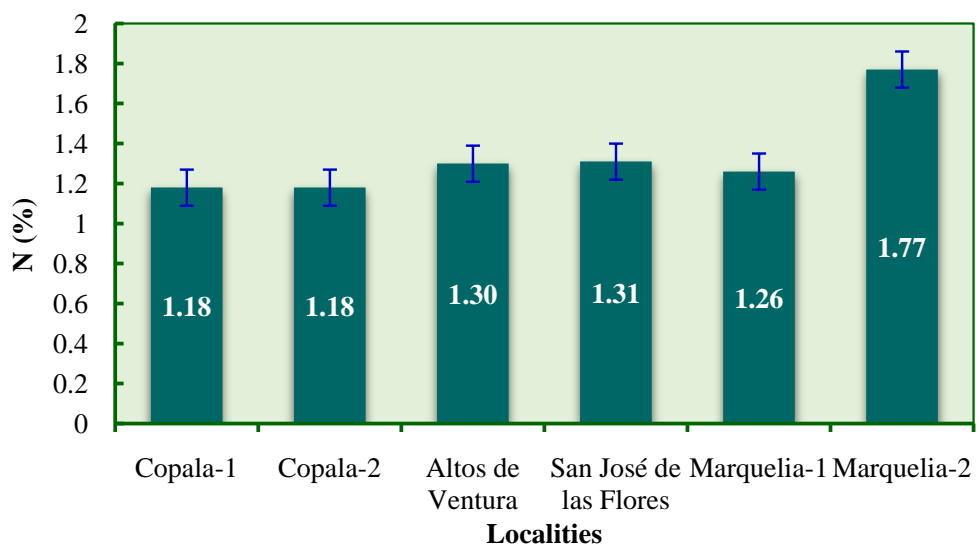

Figure 4. Foliar nitrogen content (\%) of coconut palms from Costa Chica Guerrero, Mexico with a CV of $15.5 \%$. 


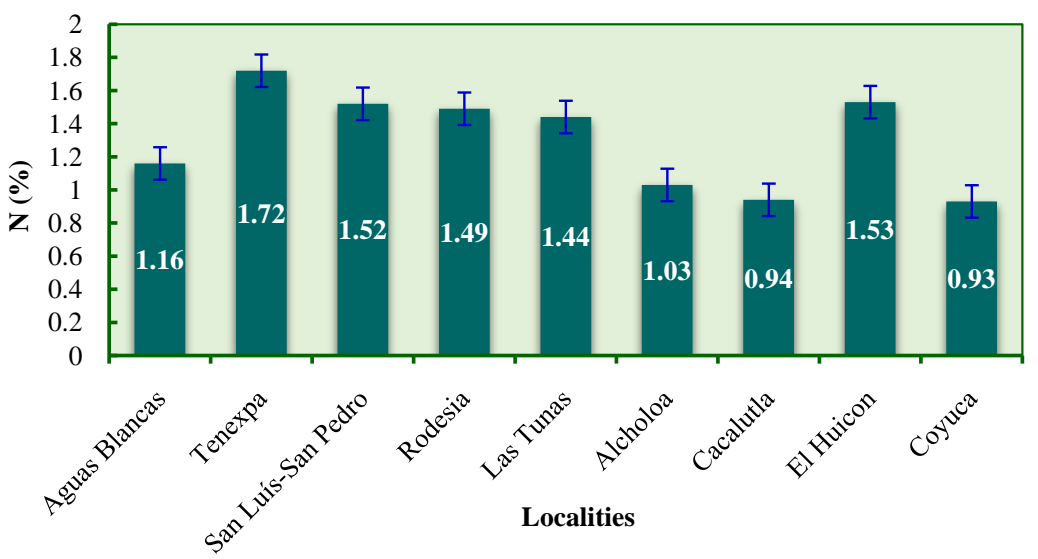

Figure 5. Foliar nitrogen content (\%) of coconut palms from Costa Grande Guerrero, Mexico with a CV of $21.2 \%$.

presented $\mathrm{N}$ deficiencies; the same deficiency trend was found in the case of the soil $\mathrm{OM}$ and $\mathrm{N}-\mathrm{NO}_{3}$ already discussed.

The foliar $\mathrm{N}$ levels, in Costa Chica, ranged from $1.18 \%$ to $1.77 \%$; Copala- 1 and Copala-2 showing the lowest values while Marquelia-2 the highest one. It seems that there is not a good correlation between foliar $\mathrm{N}$ and the soil attributes like the $\mathrm{OM}$ and $\mathrm{N}-\mathrm{NO}_{3}$ since there is a trend in Marquelia-2 to have the lower OM content than Copala1-2 but it has the highest foliar $\mathrm{N}$ level.

In Costa Grande, the Total $\mathrm{N}$ in leaf number 9 ranged from 0.93 in Coyuca to $1.72 \%$ in Tenexpa. Las Tunas is a remarkable site for showing the highest amount of soil $\mathrm{OM}$ and $\mathrm{N}-\mathrm{NO}_{3}$; however, it did not show the highest Total $\mathrm{N}$ content in leaves. So, as expected the Coefficient of Determination $\left(\mathrm{R}^{2}\right)$ were very low as shown in Table 7 .

Leaf analysis is useful in order to measure the nutritional status of the palms. However, the nutrient supply needs to be adjusted depending on different factors such as: the required nutrient level of a particular coconut material, the climate, soil properties, and crop management conditions; so a wide regional fertilizer recommendation is invalid. The critical $\mathrm{N}$ limits reported by the IRHO for the West African Tall palms, when sampling the 14th leaf, ranged from 1.8 to 2.0 per cent [33].

Related to the foregoing, Fairhurst (2003) and Fairhurst et al. (2003) [34] [35] have suggested that the optimum nutrient requirement for individual nutrients can vary over a considerable range, depending upon factors such as the age of the palms, soil moisture regime, ratio to other nutrient concentrations, type of planting material etc. Hence the optimum leaf nutrient concentration must be determined for each agro-ecological environment, taking local soil and climate conditions into considerations.

By the way, the critical limits of leaf $\mathrm{N}$ for the coastal sandy soil of the Indian state of Odisha were calculated as to be in the range of $1.52 \%$ to $1.54 \%$ [36] whilst Sobral and Santos (1987) [22] reported N deficiencies below $1.8 \%$ in the states of Bahia and Ceará (Brazil) due to soil organic matter depletion. 
The nutrients in the soil do not always guarantee a good supply to the plants. This depends on different factors such as the physical characteristics of the soil, the extension of the root system and the water potential of the root hairs [37]. Information on soil and plant analysis can be a complement when intending to formulate fertilizer recommendations.

\section{Correlation between Soil Properties and Nutritional Status of Coconut}

In Table 8 is being shown the grade of relationship between the soil attributes $\left(\mathrm{MO}\right.$ and $\mathrm{N}-\mathrm{NO}_{3}$ ) and the foliar $\mathrm{N}$ content in coconut palms as reflected by the Correlation Index $(r)$ and the Determination Coefficient $\left(\mathrm{R}^{2}\right)$.

Five out of eight (62\%) calculated $r^{2}$ s, showed a Medium correlation between soil attributes and $\mathrm{N}$ content in leaves of coconut. The only best soil attribute matching better with the foliar $\mathrm{N}$ was the soil $\mathrm{N}^{-\mathrm{NO}_{3}}$ with an $\mathrm{r}$ of 0.70 (High) and an $\mathrm{R}^{2}$ of 0.50 in Costa Chica at $30-60 \mathrm{~cm}$ deep (Figure 6). The distribution trend of points suggests that the correlation between variables can be expressed in a linear way.

Table 8. Grade of relationship between independent $(x)$ and dependent $(y)$ variables as related to their corresponding coefficients of correlation $(r)$ and determination $\left(\mathrm{R}^{2}\right)$ in soils of Costa Chica and Costa Grande (0 - 30 and $30-60 \mathrm{~cm}$ deep).

\begin{tabular}{|c|c|c|c|c|c|}
\hline Region & $\begin{array}{l}\text { Depth } \\
(\mathrm{cm})\end{array}$ & $\begin{array}{l}\text { Independent } \\
\text { variable }(x)\end{array}$ & $\begin{array}{l}\text { Dependent } \\
\text { variable }(y)\end{array}$ & $r$ & $\mathbf{R}^{2}$ \\
\hline \multirow{5}{*}{ Costa Chica } & \multirow{2}{*}{$0-30$} & $\mathrm{OM}$ & Foliar N & $-0.43(\mathrm{M})$ & 0.19 \\
\hline & & $\mathrm{N}-\mathrm{NO}_{3}$ & Foliar N & $-0.47(\mathrm{M})$ & 0.22 \\
\hline & & & & & \\
\hline & \multirow{2}{*}{$30-60$} & $\mathrm{OM}$ & Foliar N & $0.58(\mathrm{M})$ & 0.33 \\
\hline & & $\mathrm{N}-\mathrm{NO}_{3}$ & Foliar N & $0.71(\mathrm{H})$ & 0.50 \\
\hline \multirow{5}{*}{ Costa Grand } & \multirow{2}{*}{$0-30$} & $\mathrm{OM}$ & Foliar N & $0.64(\mathrm{M})$ & 0.41 \\
\hline & & $\mathrm{N}-\mathrm{NO}_{3}$ & Foliar N & $0.068(\mathrm{~L})$ & 0.004 \\
\hline & & & & & \\
\hline & \multirow{2}{*}{$30-60$} & $\mathrm{OM}$ & Foliar N & $0.57(\mathrm{M})$ & 0.33 \\
\hline & & $\mathrm{N}-\mathrm{NO}_{3}$ & Foliar N & $0.003(\mathrm{~L})$ & 0.00 \\
\hline
\end{tabular}

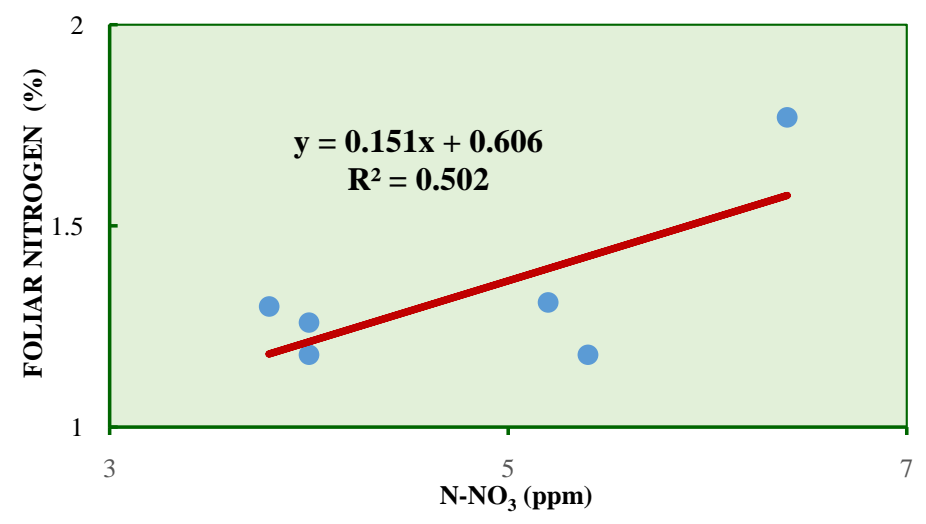

Figure 6. Correlation between $\mathrm{N}^{-\mathrm{NO}_{3}}(30-60 \mathrm{~cm})$ and foliar nitrogen in Costa Chica Guerrero, Mexico. 
The lowest correlations were found in Costa Grande with the $\mathrm{N}-\mathrm{NO}_{3}$ vs. Foliar $\mathrm{N}$ at both depths. The OM was consistent with a Medium $r$ in all regions and depths. And in some specific cases there were found negative correlations as in the case of OM and $\mathrm{N}-\mathrm{NO}_{3}$ in Costa Chica at both depths. The higher the soil attributes the lower the foliar $\mathrm{N}$. This contradictory finding was already specified by Reichardt and Timm (2004) [36].

\section{Conclusions}

The total average of soil $\mathrm{OM}(\%)$, and $\mathrm{N}-\mathrm{NO}_{3}$ in both Costa Chica and Costa Grande regions were quite low at both depths of $0-30$ and $30-60 \mathrm{~cm}$. In Costa Chica the total average of OM ranged from $1.37 \%$ to $1.33 \%$ whilst in Costa Grande ranged from $1.29 \%$ to $0.71 \%$; no one reaching the reference Medium Rate Value of $1.6 \%$ to $3.5 \%$.

The $\mathrm{N}^{-\mathrm{NO}_{3}}$ in Costa Chica ranged from 3.8 to $12.8 \mathrm{ppm}$ on the surface and from 3.8 to $6.4 \mathrm{ppm}$ in the subsoil whilst in Costa Grande N-NO${ }_{3}$ fluctuated from 6.40 to $29.64 \mathrm{ppm}$ on the surface and from 3.2 to $19.73 \mathrm{ppm}$ in the subsoil. Except for Las Tunas, all localities showed to be below the critical level of 20 ppm of $\mathrm{N}-\mathrm{NO}_{3}$. The same trend was shown with the foliar $\mathrm{N}$ contents (\%) which ranged from $1.18 \%$ to $1.77 \%$ in Costa Chica and $0.94 \%$ to $1.72 \%$ in Costa Grande (reference values from $1.8 \%$ to $2.0 \%$ ).

The statistical analysis of the soil attributes showed a great heterogeneity among localities, and the only High Correlation $(r=0.80)$ and Determination $\left(\mathrm{R}^{2}=0.65\right)$ Coefficients were found in Costa Chica between $\mathrm{OM}$ and $\mathrm{N}-\mathrm{NO}_{3}$ at $30-60 \mathrm{~cm}$ deep.

On the other hand, the best correlation model to better explain the relationship between soil attributes and Foliar $\mathrm{N}$ was found when the soil $\mathrm{N}-\mathrm{NO}_{3}$, at 30 $60 \mathrm{~cm}$ deep, was compared with the Foliar $\mathrm{N}$ in Costa Chica. For further specific fertilizer recommendations, it is very important to do deeper studies in all different agro-ecological environments.

\section{Acknowledgements}

This research work was launched thanks to the funding of the National Council of Science and Technology of Mexico (CONACYT) in closed collaboration between the Mexican Institute for Forestry, Agriculture and Livestock Research (INIFAP) and the Scientific Research Center of Yucatan (CICY). Many thanks to the farmers of Costa Chica and Costa Grande from Guerrero Mexico and the professional technicians who participated in the sampling and led by Francisco Valdovinos Barrientos from Tecpan de Galeana Municipality.

\section{Conflicts of Interest}

The authors declare no conflicts of interest.

\section{References}

[1] CDB (2016) Coconut Statistics 2015-16. Coconut Development Board, Kochi. 
https://www.coconutboard.gov.in/Statistics.aspx

[2] Selvamani, V., Maheswarappa, H.P. and Chowdappa, P. (2017) Soil Health Management in Plantation Crops. Today \& Tomorrow's Printers and Publishers, New Delhi, 27-65.

[3] Fierro, L.M. (2018) Estrategias de intervención del estado en la organización de la producción de coco en Guerrero. In: Teoría, impactos externos y políticas públicas para el desarrollo regional, Universidad Nacional Autónoma de México y Asociación Mexicana de Ciencias para el Desarrollo Regional A.C, Coeditores, México, 781-803. http://ru.iiec.unam.mx/3767

[4] ASERCA (2001) Copra; Industria molinera de trigo. Apoyos y Servicios a la Comercialización Agropecuaria. Revista Claridades Agropecuarias. No. 95.

https://info.aserca.gob.mx/claridades/marcos.asp?numero=95

[5] Granados, S.D. and López, R.G.F. (2002) Manejo de la palma de coco (Cocos nucifera L.) en México. The Revista Chapingo Serie Ciencias Forestales y del Ambiente, 8, 39-48. https://www.redalyc.org/pdf/629/62980105.pdf

[6] SIAP (2020) Avance de siembras y cosechas. Servicio de Información Agroalimentaria y Pesquera. Secretaria de Agricultura y Desarrollo Rural.

https://nube.siap.gob.mx/avance_agricola

[7] SAGARPA (2018) Convenio Modificatorio del Anexo Técnico de Ejecución Específico para la operación del Programa de Concurrencia con las Entidades Federativas para el ejercicio presupuestal 2018, que celebran la Secretaría de Agricultura, Ganadería, Desarrollo Rural, Pesca y Alimentación y el Estado de Guerrero. Diario Oficial de la Federación.

https://www.dof.gob.mx/nota_detalle.php?'codigo $=5542428 \& f e c h a=30 / 10 / 2018$

[8] Comité Nacional Palma de Coco (2012) Plan Rector Sistema Producto Nacional Palma de Coco. Cd. de México, D.F.

https://docplayer.es/69296367-Plan-rector-sistema-producto-nacional-palma-de-co co.html

[9] Santos, A.L., Monnerat, P.H. and Carvalho, A.J.C. (2004) Estabelecimento de normas DRIS para o diagnóstico nutricional do coqueiro-anão verde na região norte fluminense. Revista Brasileira de Fruticultura, 26, 330-334. https://www.scielo.br/j/rbf/a/d6sNM8GJkKdkTydrQNXYZFg/?lang=pt https://doi.org/10.1590/S0100-29452004000200035

[10] Siqueira, E.R., Ribeiro, F.L. and Aragão, W.M. (1998) Melhoramento genético do coqueiro. In: Ferreira, J.M.S., Warwick, D.R.N. and Siqueira, L.A., Eds., $A$ cultura do coqueiro no Brasil, 2nd Edition, Embrapa-SPI, Brasilia, Embrapa-CPATC, Aracaju, 73-98.

[11] Holanda, J.S., Ferreira, N.M., Silva, R.A., Chagas, M.C.M., Sobral, L.F. and Gheyi, H.R. (2007) Tecnologias para produção intensiva de coco-anão-verde. Natal: EMPARN. 40 p. Boletim de Pesquisa 34.

http://adcon.rn.gov.br/ACERVO/EMPARN/DOC/DOC000000000000575.PDF

[12] Bonneau, X., Ochs, R., Qusairi, L. and Nurlaini, L.L. (1993) Nutrition minérale des cocotiers hybrides sur tourbe, de la pépinière à l'entrée en production. Oléagineux, 48, 9-26. https://agritrop.cirad.fr/419240/1/document_419240.pdf

[13] Sobral, L.F. (1998) Nutrição e adubação do coqueiro. In: Ferreira, J.M.S., Warwich, D.R.N. and Siqueira, L.A., Eds., A cultura do coqueiro no Brasil, 2nd Edition, Embrapa-SPI, Brasilia, Embrapa-CPATC, Aracaju, 129-157.

[14] Srinivasa, R.D.V., Biddappa, C.C., Gopalasundaram, P., Upadhyay, A.K. and Zavier, T.V. (1999) Long Term Effect of Graded Fertilizer Levels on the Productivity of 
WCT Coconut in Littoral Sandy Soil of Kasaragod. Journal of Plantation Crops, 27, 201-206.

[15] Phytomonitor (2019) Archivo de análisis de fertilidad de suelos-2019 del laboratorio Phytomonitor. Calzada Aeropuerto N 7299-B. Colonia Bachigualato. Culiacán Sinaloa, México. CP. 80140.

[16] García, E. (2004) Modificaciones al sistema de clasificación climática de Köpen (para adaptarlo a las condiciones de la República Mexicana). México. UNAM, Instituto de Geografía.

http://www.publicaciones.igg.unam.mx/index.php/ig/catalog/view/83/82/251-1

[17] Espinosa, R.M., Ortiz, C.H.F.E. and Vargas, V.E. (2012) Muestreo de suelos y preparación de muestras. Instituto Nacional de Investigaciones Forestales, Agrícolas y Pecuarias. Centro de Investigación Regional del Noreste. Campo Experimental Río Bravo. Desplegable para Productores Núm. 23. http://www.inifapcirne.gob.mx/Biblioteca/Publicaciones/935.pdf

[18] Dahnke, W.C. and Vasey, E.H. (1973) Testing Soils for Nitrogen. In: Walsh, L.M. and Beaton, J.D., Eds., Soil Testing and Plant Analysis, Soil Science Society of America Inc., Madison, 97-114.

[19] Perdomo, R.R., Otero, F.M.G. and González, L.M. (2012) Validación del método del sulfato de brucina para la determinación de nitrógeno forma de nitrato en aguas superficiales. Revista Cubana de Química, 24, 155-165. https://cubanaquimica.uo.edu.cu/index.php/cq/article/view/327

[20] SEMARNAT (2002) Norma Oficial Mexicana NOM-021-RECNAT-2000, que establece las especificaciones de fertilidad, salinidad y clasificación de suelos, estudios, muestreo y análisis. Secretaria de Medio Ambiente y Recursos Naturales. Diario Oficial. http://www.ordenjuridico.gob.mx/Documentos/Federal/wo69255.pdf

[21] Magat, S.S. (1991) Fertilizer Recommendations for Coconut Based on Soil and Leaf Analyses. Philippine Journal of Coconut Studies, 16, 25-30.

[22] Sobral, L.F. and Santos, Z.G. (1987) Sistema de recomendaçóes de fertilizantes para o coqueiro (Cocos nucifera L.) com base na análise foliar. EMBRAPA-CNPCo. Documentos, 7, $23 \mathrm{p}$. https://www.embrapa.br/busca-de-publicacoes/-/publicacao/355693/sistema-de-recome ndacoes-de-fertilizantes-para-o-coqueiro-cocos-nucifera-l-com-base-na-analise-foliar

[23] Benassi, A.C., Fanton, C.J. and de Santana, E.N. (2013) O cultivo do coqueiro-anão-verde: tecnologias de produção. Vitória, ES: Incaper, 2013. 120 p.

https://biblioteca.incaper.es.gov.br/digital/bitstream/item/2711/1/BRT-cultivodocoq ueiroanao-benassi.pdf

[24] Patel, J.K., Patel, N.M. and Shiyani, R.L. (2001) Coefficient of Variation in Field Experiments and Yardstick Thereof-An Empirical Study. Current Science, 81, 1163-1164.

[25] Pimentel, F. (1985) Curso de estatística experimental. Livraria Nobel S.A., São Paulo.

[26] Muñoz, J.D., Martínez, L.J. and Giraldo, R. (2006) Variabilidad espacial de propiedades edáficas y su relación con el rendimiento en un cultivo de papa (Solanum tuberosum L.). Agronomía Colombiana, 24, 355-366. https://www.redalyc.org/articulo.oa?id=180316239020

[27] Ramírez, S.J.H., Aguilar, D.Y., Ramírez, J.G., Oropeza, S.C.M. and Cano, G.A. (2018) Materia orgánica y nitrógeno asimilable en suelos dedicados a cocotero en el estado de Guerrero, México. Revista del Centro de Graduados e Investigación. In- 
stituto Tecnológico de Mérida, 33, 116-122.

https://www.revistadelcentrodegraduados.com/2020/01/materia-organica-y-nitroge no-asimilable.html? $\mathrm{m}=1$

[28] Vidhana, A.L.P. and Somasiri, L.L.W. (1997) Use of Coir Dust on the Productivity of Coconut on Sandy Soils. COCOS, 12, 54-71.

https://pdfs.semanticscholar.org/5ffe/f20b58ccdfda4a8c3273bf4e5f5c62b91fc7.pdf? = $\mathrm{ga}=2.198197231 .135264879 .1623739204-22506612.1620707410$

https://doi.org/10.4038/cocos.v12i0.2166

[29] Bouma, J., van Ittersum, M.K., Stoorvogel, J.J., Batjes, N.H., Droogers, P. and Pulleman, M.M. (2016) Soil Capability: Exploring the Functional Potentials of Soils. In: Global Soil Security, Chapter 3, Springer, Berlin, 27-44.

https://www.researchgate.net/publication/310505620

https://doi.org/10.1007/978-3-319-43394-3_3

[30] Sales, D.B. (2006) Caracterización de la materia orgánica de suelos representativos de ecosistema amazónicos del Perú, Departamento de Ucayali, e influencia de su uso y manejo en el secuestro de carbono. Tesis doctoral, Universidad de Sevilla, España, $162 \mathrm{p}$.

https://digital.csic.es/bitstream/10261/66313/4/Caracterizaci\%c3\%b3n\%20de\%20la \%20materia\%20org\%c3\%alnica\%20de\%20suelos.pdf

[31] Batjes, N.H. (1996) Total Carbon and Nitrogen in the Soils of the World. European Journal of Soil Science, 47, 151-163.

https://www.researchgate.net/publication/271699213_Total_Carbon_and_Nitrogen in_the_Soils_of_the_World https://doi.org/10.1111/j.1365-2389.1996.tb01386.x

[32] Malhotra, S.K., Maheswarappa, H.P., Selvamani, V. and Chowdappa, P. (2017) Diagnosis and Management of Soil Fertility Constraints in Coconut (Cocos nucifera): A Review. Indian Journal of Agricultural Sciences, 87, 711-726.

https://www.researchgate.net/publication/317568008_Diagnosis_and_management of_soil_fertility_constraints_in_coconut_Cocos_nucifera_A_review

[33] Thampan, P.K. (1989) Handbook on Coconut Palm. Oxford and IBH Publishing, New Delhi, 81-157.

https://ia601600.us.archive.org/23/items/in.ernet.dli.2015.201473/2015.201473.Han d-Book.pdf

[34] Fairhurst, T.H. (2003) Environmental Aspects of Fertilizer Management in Oil Palm. In: Good Agricultural Practice and Food Safety Management in Palm Oil Industry, MPOA, Putrajaya, 1-23.

[35] Fairhust, T., Ranking, I., Mcaleer, K.W. and Griffiths, D.W. (2003) A Conceptual Framework for Precision Agriculture in Oil Palm Plantations. In: Fairhurst, T. and Härdter, R., Eds., Oil Palm. Management for Large Sustainable Yields, Potash and Phosphate Institute, Singapore, 321-332.

[36] Acharya, G.C. and Dash, D.K. (2006) Critical Levels of Macro-Micronutrients in Coconut Leaves in Littoral Sandy Soil. Journal of Plantation Crops, 34, 68-70.

[37] Reichardt, K. and Timm, L.C. (2004) Solo, Planta e Atmosfera. Conceitos, Processos e Aplicações. Editora Manole, São Paulo, 478 p. 